\title{
Teori og profession. Visioner for dansk børnelitteraturforskning $i$ videns- og mediesamfundet
}

Den danska barn- och ungdomslitteraturforskningen kom igång sent i Danmark, kanske så sent som 1998 när Center for Børnelitteratur grundades. Det menar den danska forskaren Helene Høyrup som $i$ följande artikel försöker klargöra orsakerna till denna relativt sena akademiska etablering.

De danske børnelitterære miljøer har i det tyvende århundrede været karakteriseret af et misforhold mellem gode intentioner og en manglende forsknings- og uddannelsesmæssig infrastruktur. En ordfører for et dansk politisk parti udtalte således først i 1990'erne, at det var ganske overflødigt at styrke forskning i børnelitteratur, for ville man vide noget, kunne man jo blot spørge en boghandler. I en nyere oversigtsartikel om dansk børnelitteraturforskning estimerer Torben Weinreich, tidligere leder af Center for Børnelitteratur, at under en procent af de ressourcer, Danmark hidtil har anvendt på børnelitteratur, kan karakteriseres som akademisk forskning eller uddannelse (Weinreich 2004, 32). År 0 for en akademisk forskning i børnelitteratur var, konstaterer Weinreich, etableringen af Center for Børnelitteratur ved Danmarks Pædagogiske Universitetsskole. Om end jeg bifalder det glædelige i, at vi i 1998 endelig fik et decideret center for forskning i børnelitteratur, må det frem over være en højt prioriteret social opgave at etablere uddannelsesmæssige samspil mellem teori og profession og mellem de primære, sekundære og tertiære vidensniveauer. Frem for at introducere til konkrete forskningsprojekter ønsker jeg med denne artikel at bore lidt i, hvad den relativt sene akademiske institutionalisering kan skyldes. Hvilke konsekvenser fik adskillelsen mellem en imaginær børnelitteraturteori rundet af den humanvidenskabelige udvikling, som ganske vist først i disse år er under udvikling, og professionerne? Og hvordan kunne en børnelitteraturforskning for videnssamfundet monstro se ud? 


\section{Litteraturbegrebets forvandlinger}

Bortset fra religiøse og moralfilosofiske skrifter, etikettebøger m.v., kan traditionen for, at forfattere og filosoffer forholder sig til et begreb om børnelitteratur i Danmark føres tilbage til slutningen af 1700-tallet, hvor litteraturbegrebet var under ombrydning fra et klassisk (i praksis tysk-orienteret) til et nationalt litteraturbegreb. Spændvidden mellem en formalæstetisk kritiker som J. L. Heiberg og H. C. Andersen eller B. S. Ingemann, der opfandt en ny type læserrettet litteratur centreret omkring udsigelsen til barnet, som på dette tidspunkt var en relativt bred kategori, illustrerer en dobbelthed i tiden. Den nationale kanon repræsenterede nemlig både en homogenisering af modersmålets retoriske form og en individualisering af litteraturen, idet "Romantic /---/ critics substitute a dynamic, socially responsive aesthetics based not on the fulfilment of rules but on such elusive values as the creative imagination, the common language of men and the criticism of life" (Gorak 1991, 58). Andersens eventyr viser, at barnet og det folkelige var højst relevante katalysatorer for litteraturens subjektivering og appel til bredere læserskarer. 1800-tallets barndomslitteratur indikerer et relativt "åbent" og mindre elitært litteraturbegreb, der potentielt assimilerede barnet og det folkelige i litteraturen. Romanen, hvis kanonhistorie slynger sig ind i børnelitteraturens, var dog en genrehybrid, ikke-kanonisk form, der med sin beslægtethed med hverdagssprogets heteroglossi ikke sådan uden videre lod sig indpasse. Romanen fremprovokerede derfor den første krise for modersmålet som kanon (Guillory 1993, 66): "[T]his revaluation of the cultural capital of vernacular literary works was responsible for the emergence of the category of literature itself, as well as for the first crisis in the status of the vernacular canon, the problem of assimilating new vernacular genres such as the novel" (ibid., xi). Også i en dansk kontekst er det tydeligt, at en stor del af 1800-tallets litteratur adresserer et relativt inklusivt "junior-feminint" læsepublikum, som ikke lod sig friste af Heibergs verdensfjerne vaudeviller (Clark 2003, 51), der kan læses som en slags tysk-klassisk kanon på dansk. Allerede Adam Oehlenschlägers episk-lyriske Sanct-Hansaften-Spil (1802) rummer elementer af en barndomslitteratur, der sprænger genrebegrebet i en leg med former. Andersens eventyr, der som sagt er små genrehybride romaner, gør tilsvarende krav på at være på én gang litterært kanoniske, børnerelaterede og populære. I lighed med Michel Foucaults karakteristik af litteraturen, tematiserer Andersens eventyr ofte kanon og udødelighed, idet litteraturen er en del af det moderne epistem, som det samtidig forsøger at undslippe (During 1991, 115). 
I det nittende århundrede skrev forfattere og filosoffer som Oehlenschläger, Andersen og Søren Kierkegaard også om børnelitteratur, og det er tydeligt, at denne periodes børnelitteraturbegreb er milevidt fra det tyvende århundredes forestillinger om "kiddie lit", et begreb, der i Beverly Lyon Clarks optik refererer til en parallel forklejnelse af barnet og af børnelitteraturen under modernismen. Begge gøres så at sige mindre, end de er, i takt med at litteraturen stratificeres i forhold til alder og køn. Man kan måske ligefrem sige, at det var modernismen, der skabte den specifikke børnelitteratur: "The real audience of nineteenth-century fiction is, whatever its biological age and sex, young and feminine. And a nineteenth-century call for the man-book, for the great American novel that will defy the "junior feminine", turns out to be a plea for children's literature after all" (Clark 2003, 51).

\section{Differentieringen af de litterære former og adskillelsen mellem teori og profession}

Georg Brandes, der som bekendt var en stor fortaler for litteraturens modernisering, indvarslede også det tyvende århundredes adskillelse mellem "literacy" og det litterære. I slutningen af 1800-tallet, hvor den turbulente samfundsudvikling også resulterede i en vis barndomsnostalgi og "mediepanik", opstod der både i Danmark og andre lande et markant fokus på litteraturens karakterdannende funktion, hvilket medvirkede til at afsondre litteratur for børn yderligere fra den modernistiske kanon. Differentieringen mellem kunst og karakterdannelse indvarslede desuden det tyvende århundredes opdelinger mellem den akademiske litteraturvidenskab og de formidlende professioner. Børnebibliotekarprofessionen, der ofte søgte at legitimere sit virke ud fra et begreb om "klassikere" og en slags "løftende" og lødig litteratur, der tydeligvis pegede i en anden retning end den modernistiske, distancerede sig endvidere fra det populære. Disse pionerer kan siges at have defineret børnelitteraturen ud fra et tilbageskuende litterært traditionsbegreb, som de selv skabte, og som ofte æstetiserede mødet mellem barn og voksen. I de børnelitterære miljøer udspandt der sig mellem 1880 og 1920 en række livlige diskussioner om, hvordan man bedst formidlede en "lødig", karakterdannende litteratur til børn, der kunne afbalancere det populære "smuds", som med faldet i bogpriserne var blevet lettere tilgængeligt for børn, men formodedes at være moralsk gift for deres udvikling. Chr. Erichsens "Børnenes Bogsamling" (1896) er således et tidligt eksempel på et mini-bibliotek af "klassikere", der 
kongenialt med det senere etablerede børnebibliotek (som forsøgsordning fra 1920'erne) søgte at "løfte" læseren ved hjælp af et børnelitterært traditionsbegreb, som delvist var kulturelt adapteret fra USA, og hvor eventyret ofte betragtedes som et slags fællessprog mellem barn og voksen. Pointen er her, at opsplitningen mellem litteraturens karakterdannende funktion, der blev varetaget af de professionelle "practitioners", og på den anden side den modernistiske kanon, som vogtedes af den akademiske litteraturforskning, tendentielt producerede en modsætningstænkning mellem teori og profession, mellem den litterære og den kulturelle tekst og mellem litteraturens kulturelle kapital og dens værdi i et erfarings- og livsverdensperspektiv, hvilket $\mathrm{i}$ dag både problematiseres teoretisk og $\mathrm{i}$ stigende grad er et problem for professionerne. Både modernismens affilierede læsninger og børnebiblioteket søgte at legitimere deres institutionelle virke ved at "løfte" litteraturen. I modsætning til det nittende århundredes mindre aldersopdelte læsekulturer (Clark 2003, 22: Lundin 2004, 31) indvarslede den modernistiske kanon som sagt en mere elitær stratificering af læsere, end man tidligere havde kendt, både i relation til alder og køn. I det moderne gennembrud omklassificeredes romanen f.eks. til "voksen" kunst, ofte med intellektuelle og maskuline konnotationer, hvilket indsnævrede litteraturbegrebet. Trods litteraturens modernisering fra det moderne gennembrud og frem, ofte i en retning, der fremhævede "det skrevne ords fødselsveer" (Rose 1984, 65), var den akademiske litteraturforskning længe præget af Vilhelm Andersens-konstruktionens nationale paradigme.

\section{Nykritikkens radikalisering af det akademiske standpunkt}

Nykritikkens dyrkelse, ja, fetichering, af formens ikonicitet, der synes at radikalisere det akademiske standpunkt, introduceredes i Danmark relativt sent, nemlig i 1960'erne, hvor kanon ellers var under både kulturel og teoretisk beskydning. I forhold til litteraturens begyndende postmoderne orientering, f.eks. hos Cecil Bødker (Høyrup 2006), blev nykritikken et slags "forsinket" kulminationspunkt for en ny type "diskriminatorisk" læsning, hvis underliggende præmis er, at den rigtige litteratur er den svært tilgængelige, som implicit ikke kan kaperes af børn.

Kanonteoretikeren John Guillory læser nykritikken som en bestræbelse på at legitimere litteraturvidenskaben ved at adskille det tertiære forskningsniveau fra de primære og sekundære videns- og uddannelsesniveauer. Som metode producerede nærlæsningen en 
ideologi om litteraturens sproglige sværhed (Guillory 1993, xi-xii) frem for eksempelvis at fokusere på læserperspektivet eller litteraturens kulturelle kompleksitet. I en dansk kontekst kan man endvidere pege på, at nykritikkens ideologi harmonerede godt med Humboldtuniversitetets selvforståelse som en institution for eliten frem for en uddannelse for professionerne - en strukturel opdeling mellem teori og profession, der videreførtes trods åbningen af universitetet for nye demografiske grupper, og skønt den teoretiske udvikling i spektret mellem ideologikritik og poststrukturalisme lagde op til et andet, langt fra "løftende" syn på litteratur. Modernisten Per Højholts berømte karakteristik af børnelitteraturens pædagogiske "skråt nedad-poetik" (Weinreich 1994, 7), der næsten med ubønhørlighed forhindrer den $i$ at være kunst, kan opfattes som et slags klimaks for den modernistiske indsnævring af litteraturbegrebet. I det tyvende århundrede ligner børnelitteraturens status "the doubtful status of the novel in the late nineteenth century: many consider it, like Fred's studies in Middlemarch, 'not very deep'" (Thompson 2004, 9):

Within twenty years of the publication of "The Future of the Novel" [Henry James, 1899], the views expressed in it were widespread, in particular the view that the serious novel is one that children cannot read was generally accepted among writers and critics. The impact that this exclusion has had not only on the development of children's literature but on attitudes towards it is still overwhelming. The segregation of adult's and children's literature is rationalised, even celebrated on all sides. It has assumed the status of a fact, a piece of knowledge of the world, that children read books in a different way and have to have special books written for them. (Hughes 1978, 548)

Modernismens affilierede læsninger fik en række mærkbare konsekvenser for børnelitteraturen og for dens udforskning, idet ovenstående proces reflekteredes i generel æstetisk teori, i litteraturteorien, i børnelitteraturteori og -kritik og endelig i selve børnelitteraturen (der ofte opfattedes som kendetegnet af et mindre eksperimentelt spil mellem form og indhold end den modernistisk kanoniserede litteratur. Som en sideeffekt kunne børnelitteratur undertiden opfattes som en "frirum", hvor forskelle fejres, hvilket ifølge Hughes er et træk i de britiske fantasy-traditioner. Ofte har man underbetonet børnelitteraturens formelle resonanser til andre litterære former. I Danmark har dette ikke mindst hindret en forståelse af Andersens eventyr som en slags interferensernes æstetik, der ikke blot påvir- 
kede børnelitteraturens og litteraturens nationale og internationale udvikling, men også i høj grad indvarslede modernismens radikale formeksperimenter.

Men det modernistiske litteratursyn, som promoveres af opsplitningen mellem teori og profession, fik også en række alvorlige konsekvenser for professionerne. I 1960'erne, hvor der formuleredes begyndende postmoderne positioner og poststrukturalistiske positioner i litteraturen og i "teorien", døde også det kulturelle grundlag for professionernes kanontænkning. Kulturforståelser blev relative, og folkeskolens undervisningsgrundlag var ikke længere selvfølgeligt. Set i bagklogskabens klare lys var der allerede på dette tidspunkt behov for at styrke professionernes teoretiske "gyroskop", så man kunne bevæge sig fra normative til deskriptivt-refleksive positioner. Det udvidede tekstbegreb, ideologikritikken og åbningen af universitetet for demografisk bredere grupper lagde logisk op til et øget samspil mellem teori og praksis og mellem de primære, sekundære og tertiære videns- og uddannelsesniveauer, som imidlertid ikke fuldt ud indfriedes, bl.a. på grund af adskillelsen mellem universitet og professioner. Den manglende realisering af disse samspil problematiseres i dag, hvor adskillelsen mellem en "flyvsk" teori og prakticistiske professioner står for skud. Årsagerne til den manglende institutionalisering af børnelitteraturforskningen ved alle de relevante litteratur- og medievidenskabelige litteraturuddannelser er givetvis komplekse. Det bør også fremhæves, at der i Danmark findes svagere litteratursociologiske traditioner end i Sverige. I 1990'erne etableredes en række centre for børne- og ungdomskultur og medier, men med undtagelse af Center for Børnelitteratur fokuserer disse udelukkende på de "nye" medier, selv om opdelingen mellem traditionelle og nye medier som bekendt tager sig anderledes ud i børnehøjde. I Danmark er læreruddannelsen endvidere udliciteret til specielle seminarier, der først i disse år begynder at få forskningstilknytning. Dette kan resultere i et "vilkårligt" faglighedsbegreb, der "adskiller fagene kategorialt fra videnskabsfagene, f.eks. som en kamp mellem didaktisk seminariefaglighed og såkaldt "fag-faglighed", der ikke forekommer hensigtsmæssig for videnssamfundet (Lund 2007, 82), hvis forestillinger om et fagligt løft kræver fornyet uddannelsesstrukturel tænkning. Tilsvarende er der behov for at styrke den teoretiske viden om børnelitteratur, medier og litteraturformidling i bibliotekaruddannelsen, som fik universitetsstatus i 1999, og som blandt andet skal ruste de kommende børnebibliotekarer til at kunne omsætte materialer til processer i et samarbejde med andre børnerelaterede institutioner. 


\section{Fra "kiddie lit" til multimodal barndomsforskning}

Overvejelser over barnets demokratiske rettigheder er i dag ikke blot på dagsordenen i barndomsforskningen, men tematiseres også i FNog EU-deklarationer. I sin tiltrædelsesforelæsning som Children's Laureate udtalte den britiske børnebogsforfatter Michael Rosen for nylig, at der i dag findes en markant social tendens til at instrumentalisere begrebet læsning. Blandt barnets rettigheder kan fremhæves retten til tidssvarende vidensstrukturer og til, at der forskes i dets litteratur, så læsning eksempelvis ikke gøres synonymt med teknisk læsefærdighed. Der er generelt behov for at højne den sociale bevidsthed om børnelitteraturforskningens vigtighed, og omvendt forekommer det vigtigt, at forskningen øger sin sociale signifikans og påtager sig et ansvar for at skabe hensigtsmæssige rammer omkring børns læsning og udvikling af multimodale "literacies" (Jewitt \& Kress 2003).

Den teoretiske udvikling og professionernes udfordringer bør i dag bringes i mere forpligtende samspil, hvilket kan befordre et refleksivt kanonbegreb for formidlingen og bidrage til at styrke litteraturforskningens sociale betydning. I nutidens børnelitteraturforskning genereres der eksempelvis en række tværæstetiske indsigter og forståelser, som det er en central udfordring at sætte i spil med de primære vidensniveauer, så børn i pædagogiske daginstitutioner f.eks. ikke blot møder Disney, mainstream-produkter og "klassikere", men også nutidens æstetisk eksperimenterende billedbøger. Under nykritikken nedtonedes læsningens oplevelsesperspektiv og den kulturelle kontekst, men der er i dag brug for at teoretisere de tidlige læseoplevelsers æstetik, "læselyst" og litteraturformidling, som er børnebibliotekets indgang til bogen, både i et longitudinalt og horisontalt livsverdens- og erfaringsperspektiv. Dette teoretiseringsbehov er ikke blot et dansk fænomen, for visionen om et interdisciplinært samspil mellem børnelitteraturforskningen og en teoretisk orienteret, anti-hierarkisk forskning, der bevæger litteraturforståelsen "beyond the canonic pantheon, and onto roads and flight-paths less travelled" (Thompson 2004, 9), illustrerer et generelt behov for at søge nye konstruktive veje at gå i forskning og professioner.

\section{Teori, leg og læsning}

Den teoretiske akse mellem Michel Foucault og Jacques Derrida, som kan siges at udgøre baglandet for "cultural studies", rummer ansatserne til en gryende utopi om en kritisk-ludisk læsning, en kollektiv intelligens hinsides modernistiske tekst- og mediehierarkier og 
tidligere professionsopdelinger. Som Gayatri Spivak præcist pointerer, drejer det sig i dag måske frem for alt om at "lære at læse" imod kanoniske opdelinger og mønstre, såsom " /---/ den euroamerikanske kode, der påtvinger os det samme system af voldelige udsagn, /---/ nedbryder litteraturens kraft /---/og forvandler den til et kulturelt gode: at lære at læse er at vansire den ubestemmelige figur og at forvandle den til ansvarlig tekstforståelse" (Spivak, her citeret fra Perrot 2006, 63). Som betegnelse for en gryende interdisciplinær barndoms-, litteratur- og kulturforskning foreslår Jean Perrot betegnelsen ludistik eller ludologi. Anskues litteraturen i forlængelse af legen og spillet, er det muligt at forestille sig en ny og sammensat disciplin, der skal bestå af sammenlignende litteratur, børnelitteratur, narratologi, antropologi, psykoanalyse, genetik og kommunikationsvidenskab (ibid., 63-64). Denne fremadrettede ludistik eller "læseteori" arbejder i spillet mellem tekst og kontekst, signifiant og signifié, og anskuer barnet som både skabt og skabende. I børnelitteraturens verdslige økofilosofi er overbegrebet leg og underbegreberne sensoriske relationer, symbolsk udveksling, læsning, illusion, tomhed, mening - fænomener, der både antager universelle og kulturelle træk. Analyser af legen som sprogets, æstetikkens og teoriens urform ledsages i denne forskning af sonderinger $i$ "barnets stilistiske ejendommelighed, den andens ejendommelighed" (ibid., 70), hvilket også kan bevæge analytikeren hinsides skellet mellem "høj" og "lav", kunst og populærkultur, litteratur og andre medier:

Min hensigt som kritiker og "ludist" har været at pege på det faktum, at børnebøger, der bliver godt modtaget af det unge publikum, som regel holder sig til, forvandler eller - endnu bedre - leger med det generelle mønster for 'legens og spillets logik'. En kritik, der er styret af samme princip som de børnebøger, den behandler, kommer nærmere på de unge læseres ønsker og gør fælles sag med dem i en ny 'venskabets politik' [der sigtes her til den senere Derridas tanker om at gøre verden mere gæstfri og om det 'tålmodige engagement i sproglig og etisk anden-gørelse'; se f.eks. Politics of Friendship 1997]. Om en sådan akademisk analyse stadig er sammenlignende litteratur, ludologi eller noget helt tredje, spiller ikke den store rolle. Jeg har først og fremmest ønsket at fremhæve den dobbelte bevægelse, som min metodologi i sidste ende indebærer: for de strengt litterære forskere en bevægelse fra litteratur til leg og til barnets kulturelle og psykiske egenart, og for børnekulturens eksperter en hensyntagen til de litterære kendetegn, der må tages med i betragtning for at belyse barnets stilistiske ejendommelighed, den andens ejendommelighed (Perrot 2006, 69-70). 
Børnelitteraturforskningens version af barndomsforskningen kan efter min mening tilføre den almene litteraturvidenskab, humaniora og de sociologiske forgreninger af "childhood studies" interessante nye aspekter og forståelsesformer. At fremhæve legen, ludologien og det narrative spil mellem form og indhold slår bro til det æstetiske som en central hverdagskulturel modus. En ludisk barndomsforskning undersøger ikke blot barnets prægning i sociale makrostrukturer eller teksten som adgang til individets psykiske mikrostrukturer, men må også fokusere på spillet mellem signifiant og signifié og på "teksten" som et meta-rum, hvor strukturer brydes og ombrydes. Det æstetiske i relation til spil og leg er i øvrigt en filosofisk understrøm fra Friedrich Schiller til Friedrich Nietzsche, Hans-Georg Gadamer, Johan Huizinga og Derrida, som fortjener nærmere udforskning. Børnelitteraturforskningens afart af barndomsforskningen opfatter jeg som en forgrening af "cultural studies". Sidstnævnte kan omvendt beriges af det fokus på leg, spil og ludologi, der findes i børnelitteratur. Skønt "cultural studies" ofte har haft en tendens til at fokusere på ideologiernes signifié, diskvalificerer denne bevægelse ikke nødvendigvis begrebet om det æstetiske (Bérubé 2005, 1-28), som imidlertid skal revitaliseres i forhold til "teori", hverdagskultur og et senmoderne, processuelt begreb om "multimodal literacy", f.eks. som "playing the text" og "literacies across media" (Mackey 2001; Jewitt \& Kress 2003).

"Cultural studies" kan beskrives som en bred, ideologikritisk bevægelse, hvis pejlemærke er teoretisk årvågenhed. "Metoden" slår bro mellem tekst og kontekst, hvilket altså også undertiden kan have den ulempe, at det æstetiske spil mellem form og indhold, hvorved læseren danner sin kulturelle identitet i tekstens mellemrum mellem konstrueret og konstruerende, nedtones konceptuelt (Nodelman 2005, Rudd 2003, 115 ff). Begrebet "textuality" eller diskurs implicerer, at alle medier bygger på tegnsystemer, der aktualiseres i et dialogisk samspil med læseren. Dette refleksive tekstbegreb indebærer den fordel, at forskellige læseres tekstforståelser, kanoner m.v. kan udredes analytisk, og at så forskelligartede læsere, aktører og kontekster som forskere, lærere, bibliotekarer og børn kan "skrives ind" $\mathrm{i}$ litteraturforskningen $\mathrm{i}$ arbejdet med den kulturelt formede og formende tekst (se f.eks. Lundin 2004).

\section{Børns mediale "literacies"}

Børn får i dag stillet deres tegnbegær i en mediekonvergent verden, som de samtidig skal lære at tyde. I forlængelse af "teorien" inte- 
resserer den kulturanalytiske børnelitteraturforskning sig tillige for børnelitteraturens samspil med andre medier og tegnsystemer, f.eks. visuelle, remedierede "genfortællinger" eller kommercielt merchandise, hvorved forskeren tillige forholder sig til mediernes aktuelle samspil. En tværmedial forskning kan supplere folkeskolens fokus på det skrevne ord, og Derridas term "textuality" er faktisk en præcis betegnelse for børns læsning i det multimediale mediebillede, der kræver nye former for multimodal "literacy" eller mediekompetence. I løbet af det seneste tiår har opmærksomheden på, hvordan børn lærer at læse, sat spotlys på fænomenet "textuality" og på de forskellige, indbyrdes forbundne måder, hvorpå læsere i alle aldre skaber betydning i samspil med tekster. 'At læse', hævder Meek, refererer i dag til et større antal repræsentationsformer end nogensinde tidligere: billeder, kort, skærme, designet grafik og foto kan alle anskues som tekster (Meek 2004, 4; Mackey 2001).

For de børnerelaterede professioner og institutioner kan barndomsforskningens fokus på "barnet" som en central kulturel brudflade i spektret mellem essens, konstruktion og "cross-writing" bidrage til formuleringen af nye professionsepistemologier mellem viden og ikke-viden. Anskuelsen af barnet som tærskelfigur eller i post-koloniale teorier et "mellemrum /---/, der bærer kulturens og betydningens byrde" (Bhabha1994,38, min oversættelse), fremhæver barnet som et centralt topos og refleksionspunkt i den teoretiske udforskning af relationsfænomener som viden, subjektivitet, dannelse, oplysning og betydning. I videnssamfundet peger mange kritikere på, at det centrale må være at "åbne" frem for at "lukke", hvorfor fænomener som leg, kunst, spil og refleksivitet kommer i højsædet. Videnssociologen Giorgio Agamben anskuer således "barnet" som beslægtet med sprogets apertur; det er i cæsuren mellem det sagte, det uudsagte og det uudsigelige, at betydning produceres, hvilket fremhæver sproget som materialitet og "ting" (Agamben 1998, 4).

I både dansk og international børnelitteraturforskning er vi i disse år vidne til en række grundlagsdiskussioner og tematiseringer, som peger frem mod nogle af videnssamfundets centrale udfordringer. Hvordan skaber vi f.eks. optimale samspil mellem de primære, sekundære og tertiære videns- og uddannelsesniveauer, mellem forskning og professioner. Hvordan skaber vi ambitiøse og generøse uddannelsesstrukturer, der er hensigtsmæssige for børn? Hvordan tænker vi medieudviklingen ind i forhold til børnelitteraturforskningen? Hvad kan "teorien" bidrage med i relation til børns liv? Ja, hvordan producerer børn viden?

I en oversigtsartikel om børnelitteraturforskningen efter teoriens 
"død" konstaterer Perry Nodelman, at den såkaldt lingvistiske eller retoriske vending i kølvandet på konstruktivismen blandt andet indebærer, at litteraturvidenskabelige metoder og optikker i stigende grad tages i anvendelse i analyser af "andre" kulturelle udtryk, såsom hverdagslivets og kroppens kultur, videnskabelige og praktiske diskurser og altså også børnelitteratur (Nodelman 2005). I en anglo-amerikansk kontekst er den teoretiske litteraturforskning på en måde blevet en slags metavidenskab: "It has done so because a focus on the constructedness of all sorts of phenomena studied by many different disciplines means that the phenomena are read as if they were literature" (Nodelman 2005, 9). Denne litterære eller lingvistiske vending kunne være potentielt emancipatorisk for børn, for "/---/ one of the things we know about literary works is that they have the ability to resist or outplay what they are supposed to be saying" (Catherine Belsey; her citeret fra Nodelman 2005, 9). Men børnelitteratur opfattes måske ikke som epistemologiens ludiske punkt $i$ alle kulturer. I en tysk kontekst pointerer Hans-Heino Ewers således, at fiktionens modalitet i de seneste år til dels er gledet ud af barndomsforskningens synsfelt, idet barndoms- og ungdomsforskningen i transformationen til en empirisk socialforskning helt har tabt fiktionslitteraturen af syne (Ewers 2004, 39).

Den manglende institutionalisering af børnelitteraturforskningen kan resultere i en kamp mellem paradigmer og discipliner - en slags forskningsinterne institutionaliseringsforsøg, som i dag må afløses af ekspansion, differentiering og multidisciplinær "indskrivning" (Westin 2005). I Danmark kan vi efter min mening lære meget af den internationale barndoms- og børnelitteraturforskning. Er vi på vej til at etablere en opsplitning mellem på den ene side en empirisk og barndomssociologisk forskning og på den anden side en også æstetisk orienteret børnelitteraturforskning, der potentielt interesserer sig for spillet mellem form og indhold, er vi ikke nået længere end til den første defineringsfase (Westin 2005). Vi bør i stedet spørge, hvorledes barndomssociologi og fiktionens æstetik kan berige hinanden? Vi må efter min mening lære at tænke mere inklusivt og $\mathrm{i}$ fællesskab udvikle en barndomsforskning kendetegnet af teoretisk refleksion, spillet mellem signifiant og signifié og en genoplivelse af teoriens politiske rødder (Nodelman 2005). Ludologien allierer sig i den henseende med Gayatri Spivaks visioner om en "planetarisk" og politisk litteraturforskning, der yder modstand mod globaliseringen af hegemonier. Efter teorien må komme en endnu mere radikal, engageret og kritisk pluralisme, der "lægger op til at forskere passioneret forsvarer deres passioner, og til at de intenst politisk forsvarer 
deres teorier og prøver at ændre verden" (Nodelman 2005, 10). Vi må kort sagt skabe en multimodal barndoms- og læseforskning, der opererer i skellet mellem tekst og kontekst, signifiant og signifié, barn og voksen, teori og praksis, og som foretrækker deskription frem for hierarkier.

\section{Bibliografi}

Agamben, Giorgio. Infancy $\mathcal{E}$ history: essays on the destruction of experience. London: Verso, 1998.

Bérubé, Michael. The aesthetics of cultural studies. Oxford: Blackwell, 2005.

Bhabha, Homi. The location of culture. London og New York: Routledge, 1994.

Clark, Beverly Lyon. Kiddie lit: the cultural construction of children's literature in America. Baltimore: John Hopkins UP, 2003.

During, Simon. Foucault and literature: towards a genealogy of writing. London og New York: Routledge, 1991.

Ewers, Hans-Heino. “Børnelitteratur som medium for opdagelse af barndom". Nedslag i børnelitteraturforskningen 5 (2004), 35-61. København: Roskilde Universitetsforlag.

Gorak, Jan. The making of the modern canon: genesis and crisis of a literary idea. London: Athlone, 1991.

Guillory, John. Cultural capital: the problem of literary canon formation. Chicago og London: University of Chicago Press, 1993.

Hughes, Felicity A. "Children's literature: theory and practice”. English literary history 45 (1978) 3: 542-561.

Høyrup, Helene. “Modernism for children? Cecil Bødker's Silas and the Black Mare". I Beyond Babar: the European tradition in children's literature. Sandra Beckett og Maria Nikolajeva (red.). Lanham, MD, Toronto \& Oxford: Scarecrow, 2006, 127-155.

Jewitt, Carey \& Kress, Gunther. Multimodal literacy. New York: Peter Lang, 2003.

Lund, Jørn. Det faglige løft - om greb og misgreb $i$ uddannelse og forskning. København: Gyldendal, 2007.

Lundin, Anne. Constructing the canon of children's literature: beyond library walls and ivory towers. London og New York: Routledge, 2004.

Mackey, Margaret. Literacies across media: playing the text. London og New York: Routledge, 2001.

Meek, Margaret. "Introduction: definitions, themes, changes, attitudes". I International companion encyclopedia of children's literature. London og New York: Routledge, 2004. 
Nodelman, Perry. "Editorial: what are we after? children's literature studies and literary theory now". CCL/Canadian children's literature/Littérature canadienne pour la jeunesse 31 (2005) 2:1-13.

Perrot, Jean. “Børnelitteraturen som al litteraturkritiks fremtid: genoplivelsen af en disciplin eller et nyt verdensomspændende forskningsfællesskab". I På opdagelse i børnelitteraturen: festskrift til Torben Weinreich. København: Høst \& Søn, 2006, 59-71.

Rose, Jacqueline. The case of Peter Pan; or the impossibility of children's fiction. London: Macmillan, 1984.

Rudd, David. "Betingelser for børnelitteraturens mulighed". Nedslag $i$ børnelitteraturforskningen 4 (2003), 105-131. København: Roskilde Universitetsforlag.

Thompson, Mary Shine. "Introduction". I Studies in children's literature: 1500-2000. Dublin og Portland: Four Courts Press, 2004, 9-18.

Weinreich, Torben. Skråt nedad: på vej mod en børnelitterær poetik. København: Høst \& Søn, 1994.

Weinreich, Torben. "Forskning i børnelitteratur i Danmark". Nedslag $i$ børnelitteraturforskningen 5 (2004), 11-34. København: Roskilde Universitetsforlag.

Westin, Boel. "Barnlitteraturen, (litteratur)vetenskapen och forskningen". Stockholm: Svenska barnboksinstitutet. PDF format. Tillgänglig: < http:/ / www.sbi.kb.se/BoelWkonf05.pdf > (07-11-12). 